\title{
Chapter 7 \\ Developing Twenty-First-Century Skills for Future Jobs and Societies
}

\author{
Andreas Schleicher
}

Everywhere, jobs, wealth, and individual well-being depend on nothing more than on what people know and what they can do with what they know. There is no shortcut to equipping people with the right skills and providing people with the right opportunities to use their skills effectively. And, if there's one lesson the global economy has taught us over the last decades, it is that we cannot simply bail ourselves out of a crisis that we cannot solely stimulate ourselves out of a crisis, and that we cannot just print money to get out of a crisis. ${ }^{1}$

The backdrop to twenty-first-century education is our endangered environment. Growing populations, resource depletion, and climate change compel all of us to think about sustainability and the needs of future generations. At the same time, the interaction between technology and globalization has created new challenges and new opportunities. Digitalization is connecting people, cities, countries, and continents in ways that vastly increase our individual and collective potential. But the same forces have also made the world volatile, complex, and uncertain. ${ }^{2}$

The times when we could address inequalities mainly through economic redistribution are gone, not just because this is an uphill struggle economically, but more importantly, because it does not address the much more pressing issue of social participation, where an increasingly complex world with blurring boundaries between life

\footnotetext{
${ }^{1}$ Schleicher, Andreas. March 1, 2016. Learn to Earn: Skills, Inequality and Well-being, OECD Insights. http://oecdinsights.org/2016/03/01/learn-to-earn-skills-inequality-and-well-being/.

${ }^{2}$ Schleicher, Andreas (2018), World Class: How to build a twenty-first-century school system, Strong Performers and Successful Reformers in Education, OECD Publishing, Paris.
}

\author{
A. Schleicher $(\varangle)$ \\ Director for Education and Skills and Special Advisor on Education Policy to the \\ Secretary-General, OECD, Paris, France \\ e-mail: andreas.schleicher@oecd.org
}


and work demands high levels of cognitive, social, and emotional skills from all citizens. Perhaps one day machines will be able to do much of the work that is now occupying humans and reduce the demand for many skills at work. But the demands on our skills to contribute meaningfully to an increasingly complex social and civic life will keep rising. ${ }^{3}$

\section{Issues and Challenges}

But apart from Singapore and Viet Nam, Programme for International Student Assessment (PISA) data show that most Southeast Asian countries can do much better in equipping more people with better skills to collaborate, compete, and connect in ways that lead to better jobs and better lives and drive economies forward. Just think of the economic dimension. Take a large country like Indonesia. This is a country that made good progress on PISA but still has a large minority of 15-year-olds who did not even reach the most basic level of reading and numeracy skills on the PISA assessment. If the country would fix that such that every student attains at least the PISA baseline level of performance, the economic gains could reach more than $\$ 2$ trillion in additional income for the Indonesian economy over the working life of these students.

This is important. If there is one central message emerging from the Organisation for Economic Co-operation and Development's (OECD) new Survey of Adult Skills, it is that what people know and what they do with what they know have a major impact on their life chances. For example, on average across countries, the median hourly wage of workers scoring at Level 4 or 5 in literacy - those who can make complex inferences and evaluate subtle truth claims or arguments in written texts-is more than $60 \%$ higher than for workers scoring at Level 1 or below-those who can, at best, read relatively short texts to locate a single piece of information that is identical to the information given in the question or directive, or understand basic vocabulary. Those with low literacy skills are also more than twice as likely to be unemployed. The survey also shows that this impact goes far beyond earnings and employment. In all countries surveyed, individuals with poorer foundation skills are far more likely than those with advanced literacy skills to report poor health, to believe that they have little impact on political processes, and not to participate in associative or volunteer activities. $^{4}$

It works the same way for nations: The distribution of skills has significant implications for how the benefits of economic growth are shared within societies. Put

\footnotetext{
${ }^{3}$ Ibid.

${ }^{4}$ OECD (2013), OECD Skills Outlook 2013: First Results from the Survey of Adult Skills, OECD Publishing.
} 
simply, where large shares of adults have poor skills, it becomes difficult to introduce productivity-enhancing technologies and new ways of working, which then stalls improvements in living standards. ${ }^{5}$

In short, without the right skills, people will languish on the margins of society, technological progress will not translate into economic growth, and countries cannot compete in the global economy. We simply cannot develop fair and inclusive policies and engage with all citizens if a lack of proficiency in basic skills prevents people from fully participating in society.

And for no group is all that more important than for today's youth, who cannot compete in experience or social networks in ways that older people can. ${ }^{6}$

So in one way, skills have become the global currency of twenty-first-century economies. But this "currency" can depreciate as the requirements of labor markets evolve and individuals lose the skills they do not use. For skills to retain their value, they must be continuously developed throughout life.

\section{Proposed Solutions}

So what to do? To begin, countries need to be able to better anticipate the evolution of the demand for skills: We need to know what skills will be needed to fuel economies and move up in global value chains. That is particularly important for Southeast Asia, where the next production revolution will hit particularly hard.

The coexistence of unemployed graduates on the street, while employers say they cannot find the people with the skills they need, shows clearly that more education alone does not automatically translate into better jobs and better lives. The dilemma for educators here is that the kind of skills that are easiest to teach and easiest to test are also the kinds of skills that are easiest to digitize, automate, and outsource.

The world no longer rewards students just for what they know-Google knows everything-but for what they can do with what they know. Algorithms behind social media are sorting people into groups of like-minded individuals. They create virtual bubbles that amplify our views and leave us insulated from divergent perspectives; they homogenize opinions while polarizing our societies. Tomorrow's learners will need to think for themselves and join others, with empathy, in work, and citizenship. The growing complexity of modern living, for individuals, communities, and societies, suggests that the solutions to our problems will also be complex: in a structurally imbalanced world, the imperative of reconciling diverse perspectives and interests, in local settings with often global implications, will require people to become adept in handling tensions, dilemmas, and trade-offs. Striking a balance between competing

\footnotetext{
${ }^{5}$ OECD (2019), Skills Matter: Additional Results from the Survey of Adult Skills, OECD Skills Studies, OECD Publishing.

${ }^{6}$ Schleicher, Andreas (2016). Learn to earn: Skills, inequality, and well-being in OECD (2016), Debate the Issues: New Approaches to Economic Challenges, OECD Insights, OECD Publishing, Paris (pp. 123-126).
} 
demands-equity and freedom, autonomy and community, innovation and continuity, efficiency, and democratic process-will rarely lead to an either/or choice or even a single solution. Individuals will need to think in a more integrated way that recognizes interconnections and transcends the boundaries of school subjects. At work, at home, and in the community, people will need a deep understanding of how others live, in different cultures and traditions, and how others think, whether as scientists or artists. ${ }^{7}$

But perhaps most importantly, the future is about pairing the artificial intelligence of computers effectively with the cognitive, social, and emotional skills and values of human beings. It will be our imagination, our awareness, and our sense of responsibility that will enable us to harness technology to shape the world for the better. Learning needs to enable students to create new value, which involves processes of creating, making, bringing into being, and formulating, and to generate outcomes that are innovative, fresh, and original, contributing something of intrinsic positive worth. It suggests entrepreneurialism in the broadest sense-of being ready to try, without being afraid of failing. Creativity in problem-solving also requires the capacity to consider the future consequences of one's actions, evaluate risk and reward, and assume accountability for the products of one's work.

Second, countries need to put a greater premium on skills-oriented learning throughout life instead of on qualifications-focused education, which ends when the working life begins. Skills development is far more effective if the world of learning and the world of work are integrated. It is not difficult to understand why: Compared with purely government-designed curricula taught exclusively in schools, learning in the workplace allows young people to develop both "hard" skills on modern equipment and "soft" skills, such as teamwork, communication, and negotiation, through real-world experience. Hands-on workplace training can also help to motivate disengaged youth to stay in or re-engage with the education system. But that is only working when employers are truly engaged. In our experience, this requires that work-based learning be systematically integrated into all vocational programs in a way that is mandatory, credit-bearing, and quality assured. This is something with which many Southeast Asian countries still struggle.

Employers are often in a good position to assess whether the content of curricula and qualifications meet current labor market needs; they can guide their adaptation to emerging requirements; and they can help develop qualifications and workplace training arrangements. In our work at OECD, we also learned how important it is that vocational teachers have the good technical expertise and labor market experience and that trainers in the workplace have adequate pedagogical skills. There is also a lot that we can do much earlier on in educational pathways by given children during their schooling much better information on potential careers.

Building skills is the relatively easy part of the plan; far tougher is providing opportunities for young people to use their skills. Employers might need to offer greater flexibility in the workplace. Labor unions may need to reconsider their stance on

\footnotetext{
${ }^{7}$ Schleicher, Andreas (2018), World Class: How to build a twenty-first-century school system, Strong Performers and Successful Reformers in Education, OECD Publishing, Paris.
} 
rebalancing employment protection for permanent and temporary workers. Enterprises need reasonably long trial periods to enable employers to give those youth who lack work experience a chance to prove themselves and facilitate a transition to regular employment. ${ }^{8}$

Developing skills and making them available to the labor market will not translate into better social and economic outcomes if those skills are not used effectively on the job. The way in which people use their skills at work is important in explaining differences in labor productivity.

\section{Examples of Good Practices}

There are many areas where governments can do better. The lowest hanging fruit is telling young people more of the truth about the labor market outcomes of their studies, and to incentivize educational institutions to pay attention to that. Better information and greater transparency about skills demand and supply across economies are essential for addressing skills mismatch. In the Republic of Korea, the National Skills Outlook by the Korea Research Institute for Vocational Education and Training (KRIVET) anticipates skills mismatch to make adjustment of structural reform or legislation at the national level, while it provides important guidance on future skills demand to various stakeholders such as students, parents, enterprises, and providers of education and training services. ${ }^{9}$

It is also important to create flexible labor market arrangements. Labor market arrangements, including employment protection, can facilitate or hinder the effective use of skills and address skill mismatches. These can have a particularly bad effect on young people making the transition into the labor market as well as on others such as displaced workers or those seeking to re-enter the workforce. They may also discourage workers from moving from one job to another that would offer them better skills match but also expose them to greater risk. Support for parents is one of the examples of employment conditions that facilitate participation in the labor market. In Austria, Denmark, Finland, and the Netherlands, parental leave programs to involve adjustment of working hours and part-time jobs. ${ }^{10}$

Last but not least, knowing which skills are needed in the labor market and which educational pathways will get young people to where they want to be is essential. High-quality career guidance services, complemented with up-to-date information about labor market prospects, can help young people make sound career choices.

\footnotetext{
${ }^{8}$ Schleicher, Andreas. May 28, 2013. Getting our youth back to work. ECD Education and Skills Today. https://oecdedutoday.com/getting-our-youth-back-to-work/.

${ }^{9}$ OECD (2015). OECD Skills Strategy Diagnostic Report: Korea.

${ }^{10}$ OECD (2012), Better Skills, Better Jobs, Better Lives: A Strategic Approach to Skills Policies.
} 


\section{Application of These Good Practices or Examples}

Countries are facing common challenges driven by the rapid pace of change in today's world. Megatrends such as globalization, digitalization, and demographic change are having a major impact on the way people work and live in communities, and, in turn, increasingly influence the skills that people need to navigate this complexity and uncertainty regardless of the economic status of countries. At the same time, global connectedness is also an opportunity for countries to learn from lessons and good practices identified worldwide.

For example, key policy lessons on developing relevant skills were drawn from research and international peer learning. These policy pillars are (i) encouraging and enabling people to learn throughout life, (ii) fostering international mobility of skilled people to fill skills gaps, and (iii) promoting cross-border skills policies. ${ }^{11}$ More than ten countries, including developing ones, have developed national skills strategies referring to this framework for analyzing a country's own strengths and challenges, as well as identifying good practices of other countries.

Not least, skills development is far more effective if the world of learning and the world of work are linked. In addition to more theoretical learning in schools also learning in the workplace allows people to develop "hard" skills on modern equipment, and "soft" skills, such as teamwork, communication, and negotiation, through real-world experience. Hands-on workplace training can also help to motivate disengaged youth to stay in or re-engage with education and smoothen the transition to work. $^{12}$

\section{Implication for the Future/Moving Forward}

Competent personnel who have the latest labor market information at their fingertips can steer individuals to the learning programs that would be best for their prospective careers.

Public employment services can also play a crucial role in facilitating skill matching, especially at local levels working closely with local employers as well as education and training providers. Ensuring that qualifications are coherent and easy to interpret will make a big difference. Qualifications should thus not only be clear but consistently awarded. Continuous certification that incorporates nonformal and informal learning over the working life is also essential, as is recognition of foreign diplomas. ${ }^{13}$ Countries also need to maintain and expand the most effective

\footnotetext{
${ }^{11}$ Ibid.

${ }^{12}$ Schleicher, Andreas. April 23, 2013, Norrag Blog Transforming Education into Better Jobs and Better Lives. https://www.norrag.org/transforming-education-into-better-jobs-and-better-lives/.

${ }^{13}$ Schleicher, A. The OECD Survey of Adult Skills. https://www.nier.go.jp/kankou_kiyou/143-101. pdf.
} 
active labor market measures, such as counseling, job-search assistance, and temporary hiring subsidies for low-skilled youth; and we need to link income support for young people to their active search for work and their engagement in measures to improve their employability.

But none of this is going to work unless everyone is involved: governments, which can design financial incentives and favorable tax policies; education systems, which can foster entrepreneurship as well as offer vocational training; employers, who can invest in learning; labor unions, which can ensure that investments in training are reflected in better quality jobs and higher salaries; and individuals, who can take better advantage of learning opportunities and shoulder more of the financial burden. ${ }^{14}$

Not least, digital technology now allows discovery of entirely new responses to what people learn, how they learn, where they learn, and when they learn, and enrichment of and extension of the reach of excellent teachers and teaching. Massive open online courses (MOOCs) provide a great example for digital technology in education, such as free online courses that support learning in many subjects and that are open to anyone with access to a computer and the internet. They also connect learners from across the globe with educators and with each other. Digital technology can enable teachers and students to access specialized materials well beyond textbooks and lectures, in multiple formats and in ways that can bridge time and space. They can support new ways of teaching that focus on learners as active participants. There are good examples of technology-based solutions enhancing experiential learning by supporting the project- and enquiry-based learning methods, facilitating handson activities and cooperative learning, and delivering formative real-time assessments. There are also examples of technology supporting learning with interactive, nonlinear courseware based on state-of-the-art instructional design, sophisticated software for experimentation and simulation, social media, and educational games. These are precisely the learning tools that are needed to develop twenty-first-century knowledge and skills. ${ }^{15}$

And perhaps most importantly, one teacher can now educate and inspire millions of learners and communicate their ideas to the whole world, so students do not need to put up with the teacher who happens to be around, but can choose the teacher and learning methods that speak most directly to their individual learning needs, pathways, and styles.

\footnotetext{
${ }^{14}$ Schleicher, Andreas. Better Skills, Better Jobs, Better Lives. Global Comparative Education: Journal of the WCCES Volume 1, Issue 1144.

${ }^{15}$ Schleicher, Andreas. Nov. 30, 2018. Why Good Teaching Is Crucial For Preparing Students For A Digitised World. https://hochschulforumdigitalisierung.de/de/blog/shaping-digital-turn-andreasschleicher.
} 


\section{Conclusion}

Securing employability and social progress means giving more people better skills to compete, collaborate, and connect in ways that drive our societies forward. It requires putting the premium on skills-oriented learning throughout life instead of qualifications-focused education upfront. The social partners can make an important contribution to developing curricula that include broader, transferable skills and ensuring that good quality training is available to all. Quality career guidance is essential: People who have the latest labor market information at their fingertips can help steer individuals to the education or training that would best prepare them for their prospective careers. Coherent and easy-to-understand qualifications are important to help employers identify potential employees who are suitable for the jobs they offer. Not least, helping employers make better use of their talents is key.

None of this is easy; none is done overnight. But the world is indifferent to tradition and past reputations, unforgiving of frailty, and ignorant of custom or practice. Success will go to those individuals and nations that are swift to adapt, slow to complain, and open to change. The task of governments is to help citizens rise to the challenges.

Link to the presentation material: https://events.development.asia/materials/201 60919/what-we-can-learn-pisa-and-piac.

\section{References}

OECD. (2019). Skills matter: Additional results from the survey of adult skills. Paris: OECD Skills Studies, OECD Publishing. https://doi.org/10.1787/1f029d8f-en.

OECD. (2015). OECD skills strategy diagnostic report: Korea.

OECD. (2013). OECD skills outlook 2013: First results from the survey of adult skills. OECD Publishing. https://www.oecd.org/skills/piaac/Skills\%20volume\%201\%20(eng)-full\% 20v12-eBook\%20(04\%2011\%202013).pdf.

OECD. (2012). Better skills, better jobs, better lives: A strategic approach to skills policies.

Schleicher, A. (2018). World class: How to build a 21st-century school system. Strong performers and successful reformers in education. Paris: OECD Publishing. Retrieved from https://www.oecd-ilibrary.org/docserver/9789264300002-en.pdf?expires=158 $5759574 \& \mathrm{id}=\mathrm{id} \&$ accname $=$ guest $\&$ checksum=71F1C4F4BC86DF7FF38B5304DF0FEFFC.

Schleicher, A. (2018). Why good teaching is crucial for preparing students for a digitised world. Retrieved November 30, 2018 from https://hochschulforumdigitalisierung.de/de/blog/shapingdigital-turn-andreas-schleicher.

Schleicher, A. (2016). Learn to earn: Skills, inequality and well-being. OECD Insights. Retrieved March 1, 2016, from http://oecdinsights.org/2016/03/01/learn-to-earn-skills-inequa lity-and-well-being/.

Schleicher, A. (2016). Learn to earn: Skills, inequality and well-being in OECD (2016). Debate the issues: New approaches to economic challenges, OECD Insights (pp 123-126). Paris: OECD Publishing. Retrieved from https://www.cbd.int/financial/doc/sdgs-devcoop.pdf.

Schleicher, A. (2013). Getting our youth back to work. ECD Education and Skills Today. Retrieved May 28, 2013, from https://oecdedutoday.com/getting-our-youth-back-to-work/. 
Schleicher, A. OECD. (2013) Norrag blog transforming education into better jobs and better lives. Retrieved April 23, 2013, from https://www.norrag.org/transforming-education-into-better-jobsand-better-lives/.

Schleicher, A. The OECD survey of adult skills. https://www.nier.go.jp/kankou_kiyou/143-101.pdf. Schleicher, A. Better skills, better jobs, better lives. Global Comparative Education: Journal of the WCCES, 1(1), 144. Retrieved from https://www.theworldcouncil.net/uploads/8/6/2/1/86214440/ schleicher_gcejournal_english_issue1-vol1.pdf.

The views expressed in this Chapter are those of the authors and do not necessarily reflect the views and policies of the Asian Development Bank (ADB) or its Board of Governors or the governments they represent.

ADB does not guarantee the accuracy of the data included in this Chapter and accepts no responsibility for any consequence of their use. The mention of specific companies or products of manufacturers does not imply that they are endorsed or recommended by ADB in preference to others of a similar nature that are not mentioned.

By making any designation of or reference to a particular territory or geographic area, or by using the term "country" in this Chapter, ADB does not intend to make any judgments as to the legal or other status of any territory or area.

This work is available under the Creative Commons Attribution 3.0 IGO license (CC BY 3.0 IGO) https://creativecommons.org/licenses/by/3.0/igo/. By using the content of this Chapter, you agree to be bound by the terms of this license. For attribution, translations, adaptations, and permissions, please read the provisions and terms of use at https://www.adb.org/terms-use\#openac cess.

This CC license does not apply to non-ADB copyright materials in this Chapter. If the material is attributed to another source, please contact the copyright owner or publisher of that source for permission to reproduce it. ADB cannot be held liable for any claims that arise as a result of your use of the material.

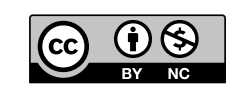

